\title{
Morbus Etymologicus? Philosophers in the Element of Etymologisation
}

\begin{abstract}
The paper presents the problem of etymologisation (folk etymology), which involves the false genealogy of meanings of concepts. Exploration and "discovering" of such false or projected meanings, as a result of the use of false genealogy has already been examined by specialists of language studies. However, it is important to note that etymologisation affects also philosophy. The paper attempts to characterize main features of this form of folk etymology and proposes to develop Hans Schnädelbach’s category of the philosophical "hermeneutic disease" (morbus hermeneuticus) to "etymological disease” (morbus etymologicus). This attempt helps to formulate the answer to the question why philosophers are tempted by etymologisations and why they so often succumb to this temptation. The main causes of this process revealed by philosophers are: the pursuit of surprise, which is the starting point for philosophical reflexion; the strong devotion to tradition and long history of their discipline; the permanent striving for both freshness and depth of philosophical language, and some kind of faith in the myth of the fundamental (antique or even older) source of all knowledge.

Although the philosophical form of the folk etymology is recognized in the paper as a substantial threat, at the same time there is some hope that studies on etymologisation may become an inspiration for philosophers.
\end{abstract}

1 Institute of Philosophy, Faculty of Humanities, Nicolaus Copernicus University in Toruń, Poland, Marcin.Zdrenka@umk.pl. 


\section{Keywords:}

etymologisation, folk etymology, language of philosophy, philosophical vocabulary, hermeneutical turn, morbus hermeneuticus

\section{INTRODUCTION: FROM GENEALOGY TO ETYMOLOGICAL DISEASE}

Contrary to what might be presumed, the key inspiration for these considerations does not stem from a general metaphilosophical reflection. It is rather the aftermath of the reflection on contemporary ethics and ways of practising it, and, most of all, on the problem of its specific "domestication" in the problem of language. It is also significant that the presented deliberations result to a large extent from a bitter self-reflection of a researcher-ethicist who had diagnosed the aforementioned condition in himself.

The crucial theoretical problem - the "domestication" of ethics in the language - is confirmed by two well-known works of recent years - After virtue by Alasdair MacIntyre (A. MacIntyre, 1981) and Sources of the Self: The Making of the Modern Identity by Charles Taylor (Taylor, 1989). The first formulates the thesis that the modern dictionary of moral terms utilised in ethical studies has long since expired. This is what MacIntyre establishes as a starting point in the opening chapter of After virtue entitled A Disquieting Suggestion (A. MacIntyre, 2013, pp. 1-6) and postulates a certain overload of this language. To Charles Taylor, on the other hand, the issues that are of key importance are narration and articulation as tools not only used in the construction of identity but also in the diagnosis and recognition of the good.

For the purpose of the conducted analyses, I am going to discuss more broadly the topic contained in MacIntyre's work entitled Three Rival Versions of Moral Enquire. Encyclopaedia, Genealogy, and Tradition (A. MacIntyre, 1990), which closes his trilogy. The author confronts three contending strategies adopted by researchers of ethics, and, indirectly - three main methods of utilisation of the language governing this discipline. Due to the limitations imposed on this article I am going to focus on the tension between the first and the second approach with an omission of an otherwise crucial aspect for MacIntyre's concept defined by him as 'tradition'.

The first way of practising ethics is symbolised by Encyclopaedia Britannica and bears this very name (encyclopaedia). Ethics is understood there in concordance with the vision developed by Louis de Jaucourt, the author of the terms morale and moralité in Diderot and D’Alambert's Encyclopaedia (A. MacIntyre, 1990, 
p. $174 \mathrm{ff}$.): it is an assertive and arbitrary ex cathedra message founded in the authority of science and the rational power that goes with it, seeking disturbances in the universal and commonly accepted system of values. Its key feature rests in the universal and timeless character of the system of norms. All its previous premature original forms were imperfect and do not deserve our attention, since in the confrontation with the mature and "complete" construction of "civilised", "rational", and, finally, "scientific" ethics, they appear primitive (A. MacIntyre, 1990, 32 ff.).

Ethics, as depicted in the encyclopaedia, collides with the concept propagated by Friedrich Nietzsche. It will be referred to by MacIntyre as genealogy due to the strong emphasis of Nietzsche's work entitled Genealogy of morals. The confrontation of both perspectives occurs on two planes. The first aspect is concerned with the role of an individual "self" in the moral reflection that the encyclopédistes seem to underestimate. They miss the sense of Nietzsche's maxim from Götzen-Dämmerung § 12: "Man does not seek happiness. An Englishman does" (A MacIntyre, 1990, p. 190). It promulgates that the problem of happiness and the paths leading to it have an individual character, and that the totalising generalisations of the encyclopaedia are missing the point in this respect. The second allegation concerns the process of mystification of the groundlessness of differentiation between the enlightened, rational and "civilised" modern ethics from mythical, irrational, and primitive past morals. Nietzsche and his followers persistently search for such a mystification. According to MacIntyre, they finally discover that the legitimisation of Victorian morality recognised in the $19^{\text {th }}$ century as model morality is equally weak as in the case of other morality models which the thinkers of that period would have seen as primitive or uncivilised.

The reflection of Alasdair MacIntyre focuses on the problem of ethics. However, the "etymological disease" in question, which rises from the genealogy postulate, does not only afflict ethicists. If we invoke here the analyses of the author of After Virtue, it is due to the fact that they constitute a perfect representation of the following three issues which are key for the considered problems.

First, it is the emphasis of the problem of language as fundamental for modern understanding of ethics, or more broadly - philosophy. It is not narrowed down merely to the implementation of the linguistic turn programme but, in fact, it consists in taking the next step - the hermeneutic turn, which will be discussed later. Showing support to the diachronic understanding of the language of ethics, in combination with the essence of the disturbing suggestion that opens After Virtue, does not only reveal the linguistic but also the hermeneutic problem. According to MacIntyre, despite the declarations made by the ethicists of the $20^{\text {th }}$ century, 
the linguistic issue remains unclear to them, particularly in analytical tradition, as the inadequacy between the modern ethical dictionary and moral practices is completely invisible for the researchers of this tradition. The meaning of the unrecognised crisis is yet to be extracted and the dictionary of ethics itself thoroughly revised. Such research work exceeds a simple observation on the genealogical or diachronic character of ethics and its language, as it requires employment of an entire range of interpretative endeavours in relation to this language, rearticulation of the ways of understanding of past ethical concepts, recognition of the paths of their evolution and seeking traces of their presence in today's descriptions of moral situations. The hermeneutic sensitivity accompanying such approach can be seen as the second thread in the conducted analyses.

The third question concerns the boundaries of understanding of the role of language and interpretation as adopted by hermeneutic philosophers. In fact, this question is connected with the suspicion that the said boundaries are being violated, which has a destructive effect on philosophy practised in a hermeneutic spirit. Such a postulate, albeit not directly addressed to MacIntyre, was articulated by Herbert Schnädelbach in the form of critique of the phenomenon known as hermeneutic disease - morbus hermeneuticus. For apparent reason reasons I am going to recall this critique, also because I myself have baldly used it to coin the name of the phenomenon as found in the title of this paper.

The hermeneutic disease that, according to Schnädelbach, affects contemporary philosophers, produces an entire group of symptoms, three of which I am going to mention.

The first is the researchers' approach derived directly from the "historical disease" (by the way: isn't the constant reference to "diseases” suspiciously unhealthy?). Friedrich Nietzsche writes what follows in Untimely Meditations:

there is a degree of sleeplessness, of rumination, of the historical sense, which is harmful and ultimately fatal to the living thing, whether this living thing be a man or a people or a culture (Nietzsche 2001, 62).

Thus, historical disease consists in reading and discussing history of philosophy rather than actual practising of philosophy. Consequently, the central object of philosophical thought no longer involves real philosophical problems but texts that treat of them. Schnädelbach defines this process as "philologisation" of philosophy. The second symptom is related to "hermeneutic ontology", i.e. the assumption that the history of philosophy is the history of impact of great texts, formulated in concordance with Odo Marquard's thesis of "being toward the text", whereas 
any attempts to exceed the boundaries of such approach allegedly pose the risk of falling beyond the limits of science. Thirdly, following Schnädelbach, the "text reading" history of philosophy, according to its supporters, has to be a universal interpretation of the entire history of this discipline. Thus, the hermeneutists put forward broad-ranging unauthorised theses and demonstrate an inclination towards far-reaching systematisations (H. Schnädelbach, 2001, pp. 221-227).

This last issue proves to be of key significance. Researchers who focus exclusively on texts, with excessive tendencies towards systematisation and a weak spot for making hasty syntheses - this is the image that I would like to present as the main background for my considerations.

\section{HERMENEUTIC TURN AND GORGIAS'S PROPHECY}

The special meaning of the critique formulated by Schnädelbach becomes clear when we take a closer look at the category of hermeneutic turn. While the term linguistic turn is already well-founded, the other one is just now gaining on its popularity. The intuition behind it seems to be shared by many authors, especially from the circle of hermeneutic philosophy, and can be reduced to research interests related to the category of understanding being brought to the foreground. However, the true embedding of "hermeneutic turn" will be probably effective only if the statements in which this concept appears are beyond being mentioned on the margins of other arguments (Fellmann, 1998, pp. 26-27; Graeser, 2002, pp. 81-90) and the synthesizing elaborations which make use of it are domesticated for good in the canon of history of contemporary philosophy (After: Przyłębski 2005, pp. 8-9; Hoy, 1993, p. 170).

There is a serious tension between the postulates of placing the category of understanding in the foreground, as arises from the hermeneutic tradition, and Schnädelbach's accusations regarding a certain "intoxication” with this perspective. Due to the limitations of this article I am not going to undertake to alleviate this tension, but rather use it as a tool to unveil the phenomenon in question which stems directly from the hermeneutic-genealogical approach. However, before the entire group of symptoms of morbus etymologicus is presented, I am going to invoke the words of Gorgias, a sophist, which constitute a tangible example of the attitude accompanying folk etymology.

Let us note that both of the above philosophical "turns", along with the previous reorientation in the history of philosophy - i.e. the transition of attention from the questions of existence to those related to cognition that founded modern 
philosophy, can be inscribed into a certain sequence, which is partially confirmed with the comment made by Andrzej Przyłębski:

This [hermeneutic - MTZ] turn is not an exotic excess of helpless and yet bored post-modern philosophy, but an immanent consequence of development of European philosophy from its Greek beginnings to scientistic, and as it turned out temporary, end (Przyłębski, 2005, p. 8).

If we can indeed speak of a consistent development of philosophy according to this pattern, we must discover with surprise how markedly accurately it is anticipated in the words of Gorgias. His most renowned statement has been treated so far only as a perfidious and ironic paraphrase of the claims made by Parmenides. Now, however, we recognise it a perspicacious ancient prophecy that amazingly accurately fulfils itself right before our eyes. Depending on the version of the relation retold by later authors, one attributed to Aristotle (De Melisso, Xenophane, Gorgia), the other that is presented in the treaty by Sextus Empiricus entitled Against the Logicians (Sextus Empiricus, Pros logikous, I, 65) - Gorgias is said to have formulated three or four theses which are thought of as the manifestation of an extreme programme of cognitive minimalism: 1. Nothing exists, 2. Even if something exists, nothing can be known about it, 3. Even if something can be known about it, knowledge about it can't be communicated to others and (after Sextus) 4. Even if it can be communicated, it cannot be understood.

Let us assume that the words detached from the original source are not so much a travestied fragment of a lost work (Nerczuk, 2004) but rather a kind of a prophecy for future European philosophy. In such a depiction Gorgias's four theses become a prophetic parable of the four stages of development of philosophical thought: starting from ontological phase in antiquity and middle ages ("nothing exists"), through epistemological turn of modern philosophy ("nothing can be known"), up to linguistic turn ("cannnot be communicated") and, finally - hermeneutic turn (“cannot be understood").

The above "finding" causes a serious confusion. In the first place, the deeply critical attitude of a philosopher commands us to oppose this simplification of perception of the history of European philosophy. Then - the methodological wariness cautions against formulation of serious theses on the fragile bases of a long lost text, known only from fragmentary paraphrases. Those who are most mistrustful could even observe that what we deal with here is a classic apophenia, i.e. an inclination to find unjustified connections between various phenomena, occurring in certain mental disorders. 
Finally, the ultimate opposition is undoubtedly raised by the category of a questionable philosophical quality - "the prophecy". On the other hand, a malicious demon of wrongly understood heuristics, the patron of rushed syntheses, or perhaps even the god of rapidity himself - Hermes (who - what a coincidence! - is also a patron of hermeneutics), whispers to our ear that this is no apophenia but rather a thrillingly relevant concept that very accurately links Gorgias's words to the history of philosophy.

Such a measure - bringing together a term, a phrase or an entire concept of the past with what is contemporarily important and meaningful, all in a single move - in fact constitutes an axis for the key action hidden behind the phenomenon referred to by specialists as etymologisation or folk etymology.

\section{WHAT IS ETYMOLOGISATION?}

Etymologisation or etymologising (also known as folk, speculative, static, synchronic etymology - Sobotka, 2015, p. 95) is defined in linguistics as "users' formulation of connections between words of a given system, sensed as valid, which are inconsistent with the historical development of words and commonly incompatible with the actual motivational relation" (Sobotka, 2015, p. 99). It is what befalls such "language users" in different situations and usually serves rhetoric, artistic, and creative purposes. To simplify, I am going to assume that etymologisation arises from two convictions: firstly, the assumption that language is subject to evolution processes, including “ageing”, as a result of which words alter or lose their original meaning and, secondly, the belief that this process can be somehow opposed in order to "recover" the lost meaning by indication of the one that is original, "proper" and "reaching the truth". Irrespective of the naivety of the latter conviction we must admit that it is reaching the classical concept of etymology formulated by Orion of Thebes preaching that "etymology [consists in] enabling interpretation of a particular matter merely by knowing how it is called, as well as discovering the reason why it is called in a given way" (Orion of Thebes, 1820, p. 173, After: Sobotka, 2015, p. 11).

In literature we can find a term that could even more bluntly define the "mythical" character of etymologisation, where etymology is in fact combined with myth: 'etymythology'. However, this name was reserved for a special and otherwise very interesting variety of folk-etymology. Etymythology is a process of revealing the real sense of a word, not simply the one forgotten in the course of natural processes of language evolution but also the one that was deliberately disguised and reserved 
by some mythical "others”. A “researcher" who practises etymythology allegedly succeeds in discovering this maliciously hidden secret. Etymologisation as such can therefore serve the preservation of all types of urban legends or conspiracy theories (Horn, 2004, p. 39).

\section{A PHILOSOPHER IN THE ELEMENT OF ETYMOLOGISATION}

Gorgias's "prophecies”, which in a way constitute a shining example of projection of a modern perception of the history of European thought on a fragmentary statement of an ancient thinker, are a pretext to recall an entire litany of related philosophical etymologisations. The dominant among them is certainly the Heideggerian derivation of the concept of truth $(\dot{\alpha} \lambda \dot{\eta} \theta \varepsilon ı \alpha)$ from negation of "what is disguised" ('non-secrets'), unauthorised from the point of view of linguists (Heidegger, 1996, pp. 201-202; Friedländer, 1964, p. 223; Sobotka, 2015, p. 29, ft. 1). Another, already partially forgotten and not entirely recognised as erroneous is Aristostle's direct derivation of the term $\tilde{\eta} \theta$ os ('permanent place of residence', 'pasture', 'character') from ع̌ $\theta$ oc ('habit') (Aristotle, Et. eud. 1220 b). Further, a seriously suspicious example is the famous derivation of the name 'man' from the discovery of the skill to 'measure' by Friedrich Nietzsche ("das Wort 'Mensch' bedeutet ja den Messenden, er hat sich nach seiner größten Entdeckung benennen wollen!” - F. Nietzsche, Der Wanderer und sein Schatten, p. 21).

We could give endless examples of etymologisations provided by philosophers. However, a much more interesting question is why philosophers so commonly succumb to the temptation of the "etymological disease"?

In order to try to answer this question let me begin with an indication of two discoveries made by the author of a pivotal dissertation on etymologisation in Polish literature - Piotr Sobotka. First of all, he observes that the situation of an etymologist working on old manuscripts bears a strong resemblance to the work of an archaeologist dealing with old artefacts (Sobotka, 2015, p. 14). Let me complement this comparison by bringing up a figure of philosopher who, contrary to much younger humanities, is well acquainted with the tradition, and dares - if only his competences allow - to reach directly to the Latin or, better so, Greek roots of his discipline. Of course here we might recognise a symptom of the hermeneutic disease diagnosed by Schnädelbach, but what we also see is an important potential. Who else if not a philosopher is authorised to translate old codes for the purposes of modern theories and practices? A philologist works on particular aspects of a language, an antiquity historian - operates within histori- 
ography; an art historian - in another narrow field defined as culture. Therefore, doesn't a philosopher enjoy special privileges that he could refer to? Indeed, his interests are not enclosed within antique philosophy even if he remains under its strong influence. A good example is Alasdair MacIntyre quoted at the beginning, who declares his attachment to Aristotle on many occasions; however, his main objective consists in his confrontation with the limitations of modern ethics.

The second recognition is connected with a certain bafflement of the author of the dissertation on etymologisation, as an interest in etymology seems to be popular also among those who do not deal with scientifically practised etymology on a daily basis (Sobotka, 2015, p. 12). The justifications regarding the development of such interests seem to be very interesting. Sobotka quotes a comment of an amateur of etymology, a programmer by profession: "Indeed, sometimes I look through an etymological dictionary for pleasure. The most interesting words for me are those that seem to be 'incomprehensible' today (...) Also sometimes various meanings encountered in the history of a particular etymological tree enable finding the meaning of a single word, a single leaf on the tree, which causes that the world becomes more profound...” (Sobotka, 2015, p. 12).

The depicted longing for wonder which further opens the door to cognition is not foreign to philosophers. They are used to the well-established conviction, which is expressed by Aristotle in the first words of Metaphysics: "all men by nature desire to know" (Met. 980 a), and the path to knowledge goes through astonishment, "for it is owing to their wonder that men both now begin and at first began to philosophize” (Met. 982 b). If language remains the first and the most accessible, shared with others and ultimately irremovable medium of cognition - irrespective of whether we as laymen are aware of the linguistic turn in the philosophy of the $20^{\text {th }}$ century - the interest in etymology becomes something absolutely natural. This is especially true for those who accept the historical variability of language that reveals itself, for instance, in the words that have "aged" and are harder to understand, as the ones that the aforesaid programmer found particularly interesting. Thus, we might say that a philosopher is not surprised by the fact that laymen reach for etymology, but rather - he may be baffled by the fact that etymologists seem to be surprised by it. Even more so if the latter themselves discover that the majority of modern Indo-European languages provide equivalents for the

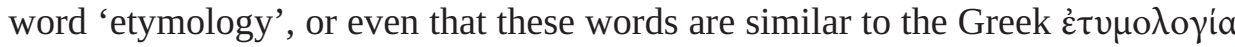
(Sobotka 2015, p. 23). This undoubtedly proves the very early popularisation of the concept of seeking the original "truth of words", and at the same time - its intriguing liveliness. 
The specific situation of a philosopher - admirer of old tales and a curious and somewhat untamed voyeur - places him near the aforementioned programmer and amateur-etymologist. However, although such an amateur draws inspiration from the richness of the past revealed by a language, the philosopher is faced with a much stronger pressure due to the historicity of his discipline. While studying it, philosophers struggle through the lushness of an esteemed centuries-old tradition produced by great predecessors. The most forthright definition of this situation is depicted by the words of Bernarde of Chartres, a thinker of the $11^{\text {th }}$ century, which may be directly referred to contemporary philosophers: "nanos gigantum humeris insidentes" - we are "dwarfs standing on the shoulders of giants". Thus, philosophers are dwarfs who discover how little they can add to an esteemed and intimidating tale. Their search for the truth must come down to a repayment of an infinite debt incurred from this tradition. If such an overpowering conviction does not cause the hermeneutic disease described by Schnädelbach, surely it will become a fertile ground for philosophers' cultivation of their historic interests, including etymological ones.

The tracking of genealogies of philosophical ideas and concepts that constitute them cannot continue indefinitely. It will remain idle if it does not end with a discovery of the most primordial arche, "the first cause", the original source where the philosopher would like the truth to be embedded. The same understanding was applied by antique language scholars in their search for the original source but also for the real meaning of words. To them, etymology as a cluster formed from

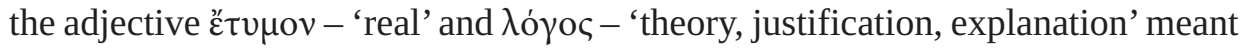
reaching the original "truth of words" (Sobotka, 2015, p. 23, 27).

Therefore, it may happen that a philosopher who utilises etymologies is not in fact searching - as most commonly he lacks the necessary linguistic competences - but rather is performing a projection of a previously learnt answer on the past. Already at the beginning of his studies he "knows" what he would like to discover. The only thing that he needs is a confirmation of his yet obscure intuitions. The more abundant the penetrated culture and its history, the easier it is to find convenient contexts and original "sources". What is worse, the worse the education of philosophers within the classical canon, the more often do they succumb to the temptation to mythologise antique culture and the linguistic resource of poorly mastered Greek and Latin. To a certain degree an embarrassing evidence of such an approach is the very title of this article: the term morbus etymologicus poorly coined in Latin, even more dilettantish since the original source of the term 'etymology' is in fact derived from Greek... 
The past forms of culture, especially ancient, unfold before philosophers a view onto a secret garden which seems even more alluring if it remains concealed with the mist of their incompetencies. This concerns both a philologically and historically undereducated amateur of wisdom as well as an impaired in this area recipient of his story. Such a soil enables etymologisations to spread easily - it suffices if the philosopher recalls a single forgotten Greek term that was once shared in the canon of well-educated men and was thus domesticated, to allow him to continue his tale, bearing only apparent wisdom and attesting to allegedly abysmal erudition, with absolute impunity.

Another crucial problem of philosophy that can lead to etymological disease consists in a simultaneous search for the depth and freshness of language. Both these features help philosophers to express general and fundamental issues as well as enable them to expose those meanings which remain disguised in popular thinking. The problem is that none of these traits are found in common colloquial language. If such a language could have reached directly for philosophical truths, have the power to oppose common sense and enable searching for what is general, disguised, not obvious - the emergence of philosophy standing in opposition to the existing forms of mythical or common thinking would not be necessary at all. On the other hand, common language remains "stale" - common meanings in its dictionary serve the established customs in communication and the language itself is incapable of going beyond its limitations. Thus, as Kołakowski will say, "the construction of new linguistic tools to express always the same questions is the fate of the philosophical endeavour” (Kołakowski, 1989, p. XII).

The rescue from the philosophical unwieldiness of common language consists in an escape towards artificial languages, whereas when it comes to individual terms - finding support in the clarifying technical terms or neologisms. This measure sometimes proves effective, as it was the case with calling the first philosophy of Aristotle 'metaphysics' that is attributed to Andronicus of Rhodes. Other attempts of this kind will be verified with time - as in the case of the name 'monoseology' postulated for the philosophy of solitude (Domeracki, 2006, p. 16). Also in other cases new technical terms are not so much neologisms as rediscovered long forgotten linguistic terms - as for instance the new popularisation of the term ‘supererogation' (Kaniowski, 1999). Some old terms also become not so much 'recovered' as employed anew after a subtle change in their meaning. We may use the following examples: the term ethos that dates back to the very beginnings of ethics, revived by Maria Ossowska's analyses, or Pierre Bourdieu's habitus. Finally, it also happens, as it is the case with the attempts to replace common philosophical terms with native equivalents, that even linguistically alluring pro- 
posals are not instilled in the language and end up as an ephemeral excess. This is what happened to the linguistic experiments depicted in Bronisław Trentowski's Chowanna (Trentowski, 1845).

Recognising the difficulties of the philosophical newspeak and wishing to avoid the "unbearable oddity" that befalls it, Kołakowski supports the idea of using the resources of existing language:

It is therefore safer to try out the possibilities embedded in existing terminology, taking care not to be carried away without resistance by its inertia and maintaining an alertness to meanings which are smuggled even subconsciously into the classification of the world in colloquial speech. All attempts at exposing hidden implications of language may be useful (Kołakowski, 1989, p. X).

The last sentence can be interpreted as a direct incentive to reach for etymologies in philosophy which, as we already know, often end in etymologisations. This also happens to great philosophers. We have indicated above a classical example of etymologisation conducted by Heidegger. Now, however, it is worth adding that the well-known passage devoted to the truth as a non-secret is closed by a paragraph that is intriguingly convergent with Kołakowski’s words:

In citing such evidence we must guard against uninhibited word-mysticism. Still, in the end it is the business of philosophy to protect the power of the most elemental words in which Da-sein expresses itself from being flattened by the common understanding to the point of unintelligibility, which in its turn functions as a Source for illusory problems. (Heidegger, 1996, p. 202).

We may read this comment as a kind of a self-warning of the author. Heidegger seems to note that the etymology of 'truth' presented by him as a 'non-secret' could have led him to an exultation with the culmination in word-mysticism. The said word-mysticism pushes towards etymologisation with the temptation of an ecstatic outburst, where again I can hear the whispers of hasty Hermes. While pursuing the said ecstasy, the philosopher is ready to sacrifice the probity of his linguistic and historical studies just to find himself in a blaze of the 'discovery' of truth which - consciously or not - he himself had instilled in the source. However - if our interpretation of Heidegger's intentions is correct - each attempt to oppose the 'diminishing' power of common sense and its ally - the well-established common language - is worth taking in defence of the power of the most elemental words. 
Besides his capabilities to seduce philosophers with false etymologies, deceitful Hermes also has his allies. The first of them is found in philosophers' conviction that the methods of their discipline remain unclear and the criteria of their application indistinct. This is particularly visible in relation to methodologically refined and well equipped sciences. The second ally is the awaken envy of wisdom lovers for the fruits of progress of natural sciences; the third is the conviction and the lost battle for souls with other narrations of man provided by disciplines that are related to philosophy - sociology, psychology or economy. Irrespective of whether the above complexes have a solid foundation, they authorise the philosopher - in his own opinion - to act as a poacher amidst the fields of more specialised sciences. This is even more true since the philosopher keeps in mind the teachings of Aristotle whose first philosophy he saw as the crowning of theoretical sciences reaching for what was most general, whereas other more detailed disciplines of knowledge he treated as menial. With such an armour he feels authorised to freely use the fruit of work of other researchers to the extent he needs. Since at the same time he is freed from any responsibility related to conducting in-depth studies on a narrower discipline, he is more of a poacher than a hunter. By using the fruit of someone else's effort he loots the already complete patterns of knowledge and on their basis formulates the most daring syntheses. Among other things, the ease of etymologisation results from the fact that the fruit of a tedious and long-term work of linguists is served in the form of handy dictionaries. Any philosopher or any philological dilettante may freely explore such dictionaries and endlessly increase his inclination to investigate the genesis of words, which etymologists find so curious. And they do so to finally exceed the limitations of 'menial' science and dare to establish auteur etymologies that, in fact, are nothing else but etymologisations.

\section{A DISEASE OR AN INSPIRATION?}

Calling the tendency to etymologise a disease would be obviously biased, as it only allows formulating a critique of the phenomenon and excludes recognising its positive aspects. Is that really so? Although etymologists themselves are critical towards folk etymology and nearly call it a disease (cf. the term un phénomène pathologique used by de Saussurre, Sobotka 2015, p. 101) the said critique is often nuanced. For instance, Sobotka notes that it should not be considered erroneous but rather seen as a manifestation of lexical competences of a language user and serve an adjustment of the resource of that language to current needs. And the philosopher is indeed in a constant need to continuously work on his "lexical 
competences”. The main source of the said need consists in the irremovable tension between onomaturgy (I am borrowing this term from Kołakowski, which is the name for the process of construction of philosophical neologisms. Kołakowski, 1989, p. 130) and the protection, as Heidegger called it, from being flattened by the common understanding. The space where the said tension occurs is a natural and permanent habitat for philosophers' activity.

Moreover, language researchers ascertain that etymology is one of the mechanisms of a linguistic modification and its "products" may be treated as "a storage for human experiences” with inscribed patterns of thinking (Sobotka, 2015, p. 282). An example can be the above mentioned tendency to etymologically combine the terms $\tilde{\eta} \theta$ o and $\varepsilon \hat{\varepsilon} \theta$ o by Aristotle. This clearly reveals the Stagirite's way of thinking about the genesis of virtues as permanent ethical dispositions which one may practice (i.e. become "accustomed to"). Therefore - whether apparent or not - the derivation of "ethics" from "habit" in inscribed within a broader theoretical concept or even perhaps - although we cannot today decide if it is true - it could constitute an element of original inspiration.

Another example, albeit one that does not constitute an immediate manifestation of folk etymology, is connected with the absence of the term 'ethics' in the first dictionary of Polish language written by Samuel Bogumił Linde. First of all, it reveals the self-sufficiency of old forms of a native language imposing moral values, where the term 'decency' (obyczajność) and its varieties prevail. Secondly, it shows strong impacts of Latin on the lexical resource of the Polish language, which confirms, with the absence of references to 'ethics' derived from Greek, domestication of such terms as 'morality' (moralność) or the adjective 'moral' (moralny) (this is also confirmed by Słownik polszczyzny XVI wieku (The Dictionary of the Polish Language of the $16^{\text {th }}$ Century) where we can only find the term 'morale' (morale), 1984, v. XV, pp. 2-3). The only term that is directly interlinked with 'ethics' is 'etiquette' (etykieta) which Linde derives from the German 'Etikette'. Modern research finds an original connection of this term with French language (étiquette) and claims it is only derivatively connected with German. Andrzej Bańkowski, although not beyond all doubt, contemplates the possibility that the original use of this word to describe 'court etiquette' could have been derived from 'small court etiquette', i.e. the diminutive form for 'ethics'. (Bańkowski 2000, v. I, pp. 352-353). The simplified indication of the origin of the word 'etykieta' provided by Linde, alongside the acknowledgement of the presence or absence of certain terms in the language resource, allow for making conjectures regarding the history and shaping of the technical language of ethics. In this as well as in other similar cases, etymologisations - although in the provided example we are rather 
faced with an ordinary simplification - may thus constitute the basis for historical diagnoses of a more general nature than merely linguistic.

We should not disregard the excitement connected with the search for and "discovery" of the original truth of a word which pushes amateur-etymologists towards dictionary studies. In fact, during such moments of astonishment and discovery they show the very type of elation that philosophers long for. Of course, we can already guess that the said excitement may lead us astray if, following the whispers of deceitful Hermes - the patron of hasty and simplified combinations of ideas, hasty syntheses, brilliant although poorly established points - we are driven towards pure fantasies. Let the philosopher to whom this has never happened be the first to cast a stone at Hermes. The long craved intellectual satisfaction of the philosopher, i.e. the award for his tedious and systematic work, is what we experience definitely too rarely. It is hardly surprising that wisdom lovers so badly wish to help it manifest itself.

We should also remember about those to whom we speak as philosophers. If we ourselves are to avoid Hermes's seduction, shouldn't we then refrain from using his tricks in teaching philosophy to students? Etymologisation is characterised by its striking handiness, just like other concise forms of a condensed message, for instance an aphorism or a maxim. Etymology - proper or folk - of a single term is therefore concise, creates an impression of being simple and easy to use in one's account. As such, it can constitute an excellent, effective, and impressive didactic tool. The rich and old dictionary of philosophy demands etymology at every step, and the etymology of each single term becomes a separate tale whose path is easily marked out with the use of a ready tool in the form of etymological dictionaries. And so, in an easy way the philosopher may unfold before his students the image of depth that he himself has not developed but which appears to be abysmal due to the fact that it was sanctioned by the centuries-old and esteemed genealogy of a term. However, since the matter is usually concerned with a single term we may easily speak of a single, perhaps slightly enhanced aphorism, which the philosopher can develop before the eyes of his fascinated students. Is working according to this method a cheap way of avoiding solid philosophical work due to the fact that the words submerged in history to a certain degree already speak for themselves? Not necessarily. In fact, this is where the greatest power of proper etymology is revealed, as is that of its permanently doped sister - etymologisation. This is the role of inspiration.

If proper caution is maintained and numerous reservations are imposed, recalling the genesis of terms may prove to be an inspiring incentive for philosophy. This is particularly visible with regard to basic yet equivocal concepts of a given 
discipline. An especially significant example is the etymology of the term 'ethics' expanded from $\square \theta$ os, which used to signify a 'pasture', 'permanent place of residence' or 'character'. Each of these meanings, marked with complex history and ambiguity opens possibilities for philosophical reflections on which we can base varied and endless stories. The said stories will repeatedly exceed the boundaries of correctness drawn up by professional etymologists or even end in a vulgar etymologisation. But in the name of a philosophical inspiration we are willing to take this risk.

The main problem of etymologisation in philosophy consists in the fact that the recognition of the risks that are linked to it occurred relatively late or philosophers still do not realise that they exist at all. This is both depressing and consoling. Depressing, because it makes us realise how long otherwise perspicacious philosophers remained blind to this affliction. What is consoling, on the other hand, is the fact that once the philosopher acquires self-awareness, it then acts as a vaccine and make him immune to Hermes's whispers. In this perspective, development of more suited tools to study etymologisation than those presented here can reveal that indeed it is not an occupational disease of wisdom lovers but rather an important element of their self-reflection and a place to be further philosophically organised.

However, is the self-reflection vaccine a sufficient protection against the temptation of etymologisation? Not necessarily. But certainly it is enough to enhance vigilance and further refine the tools of reflection on language - the basic philosophical problem of today - if we are to believe the prophecy of Gorgias or even adopt the theses of the $20^{\text {th }}$-century turns in philosophy. If we tackle the problem of language while being aware of the temptations of etymologisation and keeping in mind the Heideggerian warning against falling for word-mysticism - the more effectively will we be able to fight with the deprivation of meanings of philosophical terms caused by common language. Even if this difficult fight occasionally forces us to stand arm in arm with questionable allies as, for instance, folk etymology.

\section{References:}

Bańkowski, A. (2000). Etymologiczny słownik języka polskiego [Etymological dictionary of the Polish language]. Warsaw: PWN.

Domeracki, P. (2006). Meandry filozofii samotności [Meanders of Philosophy of Solitude]. in: W. Tyburski, P. Domeracki. Zrozumieć samotność. Studium interdyscyplinarne [Understand loneliness. Interdisciplinary Study] (pp. 15-25). Toruń: Wydawnictwo Naukowe UMK. 
Fellman F. (1998). Orientierung Philosophie. Was sie kann, was sie will. Reinbeck b. Hamburg. Rowohlt-Taschenbuch-Verlag.

Friedländer P. (1964). Plato. An Introduction. Transl. by H. Meyerhoff. New York: Harper.

Graeser A. (2002). Positionen der Gegenwartsphilosophie. Vom Pragmatismus bis zur Postmoderne. München: C.H. Beck Verlag.

Heiddeger M. (1996). Being and Time. Transl. by J. Stambaugh. New York: State University Press.

Hoy, D.C. (1993). Heidegger and the Hermeneutic Turn. In: Guignon, Ch. (1993). The Cambridge Companion to Heidegger. Cambridge: Cambridge University Press.

Horn, L. (2004). Spitten image: Etymythology and fluid dynamics. American Speech 79, pp. 33-58.

Kaniowski, A.M. (1999). Supererogacja. Zagubiony wymiar etyki. Czyny chwalebne w etykach uniwersalistycznych [Supererogation. Lost Dimension of Ethics. The Glorious Deeds of the Universalist's Ethics], Warsaw: Oficyna Naukowa.

Kołakowski, L., \& Czerniawski, A. (1989). The Presence of Myth. Chicago: University of Chicago Press.

MacIntyre, A. (2013). After Virtue. A Theory. A Study in Moral Theory. London: Bloomsbury Academic.

MacIntyre, A. (1990). Three Rival Versions of Moral Enquire. Encyclopaedia, Genealogy, and Tradition. The Gifford Lectures. University of Notre Dame Press.

Nerczuk, Z. (2004). Traktat Gorgiasza „O niebycie” w parafrazie Sekstusa Empiryka [Gorgias's Treatise “On the nonexistence” in Paraphrase of Sextus Empiricus] (pp. 185-201). in: I. Mikołajczyk (ed.), Sapere Aude. Księga pamiątkowa ofiarowana Profesorowi dr hab. Marianowi Szarmachowi z okazji 65 rocznicy urodzin. Toruń: Wydawnictwo UMK.

Nietzsche, F. (2001). Untimely Meditations. Trans by R.J. Hollingdale, Cambridge: Cambridge University Press.

Przyłębski, A. (2005). Hermeneutyczny zwrot w filozofii [The Hermeneutic Turn in Philosophy]. Poznań: Wydawnictwo Naukowe UAM.

(1984). Słownik polszczyzny XVI wieku [Dictionary of Polish the XVI century]. Warsaw: Zakład Narodowy im. Ossolińskich, Wydawnictwo PAN.

Sobotka, P. (2015). Etymologizowanie i etymologia [Etymologising and Etymology]. Warsaw: Bell Studio.

Schnädelbach, H. (2001). Morbus hermeneuticus - tezy na temat pewnej choroby filozoficznej [Morbus hermeneuticus - Thesis on a Philosophical Illness]. in: H. Schnädelbach. Rozum i historia. Odczyty i rozprawy [Reason and History. Lectures and Studies] (pp. 221-227), Warsaw: Oficyna Naukowa.

Taylor, Ch. (1989). Sources of the Self. The Making of the Modern Identity. Cambridge University Press.

Trentowski, B. (1845). Chowanna czyli system pedagogiki narodowej [Chowanna, or the System of National Pedagogy]. Vol. I. Poznań. 